Article

\title{
The Effects of Rice Husk Biochar Rate on Arbuscular Mycorrhizal Fungi and Growth of Soursop (Annona muricata L.) Seedlings
}

\author{
Nur Saidahtul Nadiah Harun ${ }^{1}$, Noraini Md. Jaafar ${ }^{1, *(1)}$ and Siti Zaharah Sakimin ${ }^{2}$ \\ 1 Department of Land Management, Faculty of Agriculture, Universiti Putra Malaysia, Serdang 43400, \\ Malaysia; nsnadiahharun@gmail.com \\ 2 Department of Crop Science, Faculty of Agriculture, Universiti Putra Malaysia, Serdang 43400, Malaysia; \\ szaharah@upm.edu.my \\ * Correspondence: j_noraini@upm.edu.my; Tel.: +603-97694953
}

Citation: Harun, N.S.N.; Jaafar, N.M.; Sakimin, S.Z. The Effects of Rice Husk Biochar Rate on Arbuscular Mycorrhizal Fungi and Growth of Soursop (Annona muricata L.) Seedlings. Sustainability 2021, 13, 1817. https://doi.org/10.3390/ su13041817

Academic Editor: Arnab Bhowmik Received: 26 December 2020

Accepted: 22 January 2021

Published: 8 February 2021

Publisher's Note: MDPI stays neutral with regard to jurisdictional claims in published maps and institutional affiliations.

Copyright: (c) 2021 by the authors. Licensee MDPI, Basel, Switzerland. This article is an open access article distributed under the terms and conditions of the Creative Commons Attribution (CC BY) license (https:// creativecommons.org/licenses/by/ $4.0 /)$.

\begin{abstract}
Soursop (Annona muricata L.) is increasingly planted in Malaysia for its agronomical importance as a multipurpose plant with medicinal and health benefits. However, there is limited information on soursop cultivation in Malaysia. Soursop can be inoculated with arbuscular mycorrhizal fungi (AMF) as a sustainable approach for successful seedlings growth before transplanting to field. As a beneficial symbiotic soil microorganism, AMF has been known as biofertilizer which can improve soil conditions and plant growth. Following the need to understand the soil management using soil beneficial microorganisms for soursop cultivation, this experiment aimed to determine the effects of AMF and biochar on the growth of soursop seedlings. The polybag experiment was conducted under glasshouse conditions at Farm 15, Faculty of Agriculture, UPM Serdang, Selangor. The study was arranged in Randomised Complete Block Design (RCBD) with eight treatments comprising different rates of rice husk biochar (RHB), with and without AMF and four replications. The treatments were; T1 (Control), T2 (AMF only), T3 (-AMF with $10 \mathrm{t} /$ ha RHB), T4 (+AMF with 10 t/ha RHB), T5 (-AMF with 15 t/ha RHB), T6 (+AMF with 15 t/ha RHB), T7 (-AMF with $20 \mathrm{t} / \mathrm{ha} \mathrm{RHB}$ ) and T8 (+AMF with $20 \mathrm{t} / \mathrm{ha} \mathrm{RHB}$ ). Plant growth measurement were determined upon harvesting after four months of planting. Shoot and root biomass, leaf area meter, root surface area and root length were found significantly highest in soursop seedlings grown in soils amended with $10 \mathrm{t} /$ ha RHB with or without AMF as compared to control. It was concluded that RHB, either individually or when in combination with AMF, had significantly improved the growth performance of soursop seedlings at nursery stage. Therefore, earliest inoculation of soursop seedlings with AMF at nursery stage could ensure successful mycorrhizal establishment and growth performance of soursop seedlings before transplanted under field condition.
\end{abstract}

Keywords: glasshouse; arbuscular mycorrhiza fungi; rice husk biochar; soursop

\section{Introduction}

In Malaysia, rice husks have been pyrolyzed into rice husk biochar (RHB) and used as soil amendments to increase soil carbon sequestrations and plant growth [1-5]. Other researches elsewhere have reported that carbonised RHB stimulated AMF formation of some crop plants by enhancing soil physical properties when it was added to the top soil [6].

Incorporation of arbuscular mycorrhizal fungi (AMF) with biochar has been highly adopted as one of soil management tools in various agroecosystems services. Both AMF and biochar have been revealed to improve soil physical, chemical and microbial properties as well as plant growth [6-8]. Numerous studies have also indicated improvement in AMF root colonisation and sporulation due to biochar application into soil [6,7]. Biochar properties and varying factors including biochar rate and type were some of the underlying factors for the biochar direct and indirect mechanisms as well as biochar effects in soil $[2,9,10]$. 
Other studies also indicated the properties of RHB consisting of silicon and potassium in amending soils as the contributing factors for the varying effects to soils [11].

In view of biochar application rate, previous studies have shown that maize plant performed better when amended with RHB at higher rate between 10 to $15 \mathrm{t} / \mathrm{ha}$ [12]. Studies locally conducted (in Malaysia) have shown that the range of RHB rate being applied to soils can be between 5 to $30 \mathrm{t} / \mathrm{ha}$ and are usually used in few trials [13]. For example, a higher RHB rate $(<30 \mathrm{t} / \mathrm{ha} \mathrm{RHB})$ increased plant productivity, such as corn and rice, by $11 \%$ [2]. According to [14], better results in oil palm seedlings was observed between empty fruit bunch (EFB) biochar at $1.5 \%$ and $30 \%$ of compost in addition to $75 \%$ of fertilizer. Previous study again showed that interaction of $10 \mathrm{t} /$ ha RHB and $2.5 \mathrm{t} /$ ha chicken dung promoted growth of Phyllanthus niruri in terms of yield, heavy metal concentration and nutrient uptake [15].

Whilst conflicting results in plant growth were shown from varying RHB application rate, the effects were not studied and reported for AMF. Previous studies elsewhere have suggested that deep banded biochar derived from wood application at $3 \mathrm{t} / \mathrm{ha}$ enhanced AMF colonisation [9]. Charcoal from secondary forest wood addition at 5 and $11 \mathrm{t} / \mathrm{ha}$ as reported [16] produced higher results in stoner and grain yield. Higher colonization in mycorrhizal roots for subterranean clover and wheat were observed at $50 \mathrm{t} / \mathrm{ha}$ woody biochar [8]. Other research discovered biochar from five types (oil mallee, rice husk, New Jarrah, Old Jarrah and wheat chaff) at rates $<50 \mathrm{t} /$ ha application helped improved wheat seed germination [17]. Other studies indicated RHB rate of $10 \mathrm{t} / \mathrm{ha}$ can increase productivity of crops which varied with type of crop, with greater improvement in legume crops $(30 \%)$, vegetables $(29 \%)$ and grasses $(14 \%)$ than cereal crops such as corn $(8 \%)$, wheat $(11 \%)$ and rice $(7 \%)$, as reported by [18]. Similar observation has been discovered by [19] in both RHB and sawdust biochar with $10 \mathrm{t} /$ ha produced highest weight of sesame seed as well as enhanced soil moisture content and soil porosity including soil $\mathrm{pH}$. Wheat seed germination was increased with $10 \mathrm{t} / \mathrm{ha}$ as a single dose application [20]. There are suggestions that biochar can be a catalyst for soil microbial activity which cater as habitat and enhanced, soil fertility and water holding capacity, thus increasing crop growth and yields [21,22].

Based on the potential effects of RHB as the soil amendments for soursop cultivation under tropical conditions, local evaluation of AMF and RHB application to Malaysian soil in regards to the amount or rate of application was relevant to fill the knowledge gap. Therefore, the study on soursop seedlings in regards to AMF and RHB application under Malaysian soil was conducted with the objectives:

i. To determine the establishment of AMF symbiosis with RHB addition at varying application rate.

ii. To determine the effects of RHB and AMF symbiosis on growth of soursop seedlings on soil biological and chemical properties.

\section{Materials and Methods}

\subsection{RHB Mixture to Soils Preparation and Mycorrhizal Inoculation}

Rice husk biochar (RHB) were supplied by Padiberas Nasional Berhad (BERNAS), Malaysia. The RHB was alkaline with $\mathrm{pH} 10$ and $22 \% \mathrm{C}$. The surface area of RHB was $115.82 \mathrm{~m}^{2} / \mathrm{g}$, pore volume was $0.23 \mathrm{~cm}^{3} / \mathrm{g}$. Different rates of RHB were placed in 128 designated polybags containing soils collected from Ladang Kongsi, Universiti Putra Malaysia (UPM), Serdang (N 02.98004, E 101.71281). The collected soils were air dried and sieved using a $2 \mathrm{~mm}$ sieve to separate the soil from coarse and roots. Two kilograms of soil were placed in designated 128 polybags, respectively. Soils was characterised and identified as Serdang Series soil which consisted of $1.40 \% \mathrm{C}, 0.16 \% \mathrm{~N}$ and $\mathrm{pH}$ of 5.35 .

The arbuscular mycorrhizal fungi (AMF) inoculum of Glomus mosseae were obtained from Soil Microbial Laboratory, Department of Land Management. The spores of Glomus mosseae were propagated in sterilised sand with corn as a host. Approximately $10 \mathrm{~g}$ of Glomus mosseae inoculant with 100 spores was placed into a hole in the centre of the polybag 
by placing it below the root of the plants. For non-inoculated plants, $10 \mathrm{~g}$ of sterilised soil were used to replace Glomus mosseae in each polybag in order to provide the same soil condition.

\subsection{Experiment Setup}

The experiment was carried out under glasshouse condition located at Farm 15, UPM Serdang, Malaysia using 2-month-old soursop seedlings (seedlings initially propagated in propagation tray). The plants were transplanted and grown in polybags containing Serdang Series soils mixed with respective four rates $(0,10,15$ and $20 \mathrm{t} / \mathrm{ha})$ of RHB and inoculated with and without AMF. The study was arranged in Randomised Complete Block Design (RCBD) with 2 factors and replicated 4 times. The treatments were T1 (Control), T2 (+AMF without $0 \mathrm{t} / \mathrm{ha}$ RHB), T3 (-AMF with $10 \mathrm{t} / \mathrm{ha}$ RHB), T4 (+AMF with $10 \mathrm{t} /$ ha RHB), T5 (-AMF with 15 t/ha RHB), T6 (+AMF with 15 t/ha RHB), T7 (-AMF with $20 \mathrm{t} / \mathrm{ha} \mathrm{RHB}$ ) and T8 (+AMF with $20 \mathrm{t} / \mathrm{ha}$ RHB). A total of $10 \mathrm{~g}$ of AMF (was added into the treatment of AMF) and $10 \mathrm{~g}$ of autoclaved soil were added into the treatments without AMF in order to provide the same soil condition.

The 2-month-old soursop seedlings were transplanted into the polybag according to the treatment with one plant per polybag. For control, no AMF and RHB were applied. Approximately $10 \mathrm{~g}$ of AMF were added into the treatment of AMF and $10 \mathrm{~g}$ of autoclaved soil were added into the treatments without AMF in order to provide the same soil condition. The treated seedlings were evaluated after 120 days after transplanting.

\subsection{Plant Growth Analysis}

Soursop plant heights were measured prior to harvesting. The plant height was measured from the base of the stem until the tip of the shoot using measuring tape. Fresh leaves, stem and root were weighed to obtain the fresh weight of leaves, stem and root. Leaves, stem and root were placed in separated brown paper and was dried in the oven with the temperature of $50{ }^{\circ} \mathrm{C}$ for about 3-4 days. Dry weight of leaves, stem and root were determined and recorded. The fresh leaves were used to measure specific leaf area (SLA). The leaf area was measured with a LI-3000C portable leaf area meter (Lincoln, Nebraska, USA).

\subsection{Determination of Root Analysis (Root length, Root Volume, Root Surface Area)}

Roots were rinsed with tap water to remove soil particles before being scanned by Epson Expression 1680 with WinRHIZO software programme. The roots were analysed in WinRHIZO for root length, root volume and root surface area determination. After that, known weights of fresh root samples were placed in separated brown paper for dry biomass purpose by oven dried under temperature $50^{\circ} \mathrm{C}$. The loss moisture was calculated for conversion of whole roots.

\subsection{Determination of Soil Microbial and Mycorrhizal Analysis}

Spore count was determined using wet sieving method [23]. About $10 \mathrm{~g}$ of soil sample was weighed using digital weighing balance and placed in $100 \mathrm{~mL}$ beaker. The beakers were filled with $100 \mathrm{~mL}$ water. The content was stirred and soaked for $30 \mathrm{~s}$ to allow the soil mixture to settle. The soil mixtures were poured to the arranged sieves of $250 \mu \mathrm{m}$ at the top, $106 \mu \mathrm{m}$ and $45 \mu \mathrm{m}$ at the bottom, and were rinsed continuously using slow running tap water. The soil and debris retained on the sieved then was poured into the petri dish and examined under stereo microscope.

The total microbial population of bacteria, fungi and actinomycetes in the soil was enumerated using total plate count technique [24]. The soil sample was put into conical flask containing $95 \mathrm{~mL}$ distilled water and closed with aluminium foil. The flask $\left(10^{-1}\right.$ dilution factor) was shaken for $5 \mathrm{~min}$ by hand to ensure microbial cells were in soil suspension. Three types of agar were prepared for microbial population; Nutrient Agar (NA), Rose Bengal Streptomycin Agar (RBSA) and Actinomycin Isolation Agar (AIA). 
Colonies formed were counted and population were calculated as colony forming unit (cfu) dry soil. Only petri dishes containing 30-300 colonies were counted and determined.

Mycorrhizal root infection was determined using $1 \mathrm{~g}$ of fresh and cleaned roots, randomly selected with length of 1 to $2 \mathrm{~cm}$. The root segments were then placed in $25 \mathrm{~mL}$ McCartney bottle and cleared by soaking the roots with $\mathrm{KOH}$; the $\mathrm{KOH}$ was replaced every $24 \mathrm{~h}$ for 4 days before the roots were heated in a water bath about $1 \mathrm{~h}$ and $30 \mathrm{~min}$ at $90{ }^{\circ} \mathrm{C}$. Then, the roots were taken out from the water bath and cooled. Next, the roots were rinsed with distilled water and then soaked in $1 \mathrm{~N}$ Hydrochloric acid $(\mathrm{HCl})$ to acidify the roots before being stained with the staining solution (mixture of $50 \mathrm{~mL} \mathrm{1 \%} \mathrm{HCl,} 450 \mathrm{~mL}$ glycerol, $500 \mathrm{~mL}$ distilled water and $0.25 \mathrm{~g}$ trypan blue to produce $1 \mathrm{~L}$ staining solution). Then, the roots were heated again for $5 \mathrm{~min}$ in water bath so the staining solution fully attached to the roots before being mounted on glass slides. The stained roots segments were observed under microscope for the presence of mycorrhizal arbuscules, vesicles and hyphae (positive) and infection percentage was calculated from positive sections over the observed overall sections.

\subsection{Statistical Analysis}

All the results and data for this experiment were analysed using two-ways analysis of variance (ANOVA) and the data analysis were conducted by using Statistical Analysis System (SAS 9.4). Significant difference was analysed using Tukey's Honest Significant Difference (HSD) at $p \leq 0.05$.

\section{Results}

\subsection{Effects of AMF and RHB on Soursop Plant Growth}

Data presented in Figure 1 showed that interaction of AMF and RHB (AMF*RHB) had significant effects $(p \leq 0.05)$ on plant height throughout four months after transplanting. A total of 120 days after transplanting, T6 (+AMF + $15 \mathrm{t} /$ ha RHB) showed the highest plant height compared to AMF alone (T2) or when compared with other RHB amended soils without AMF inoculation (T3, T5 and T7).

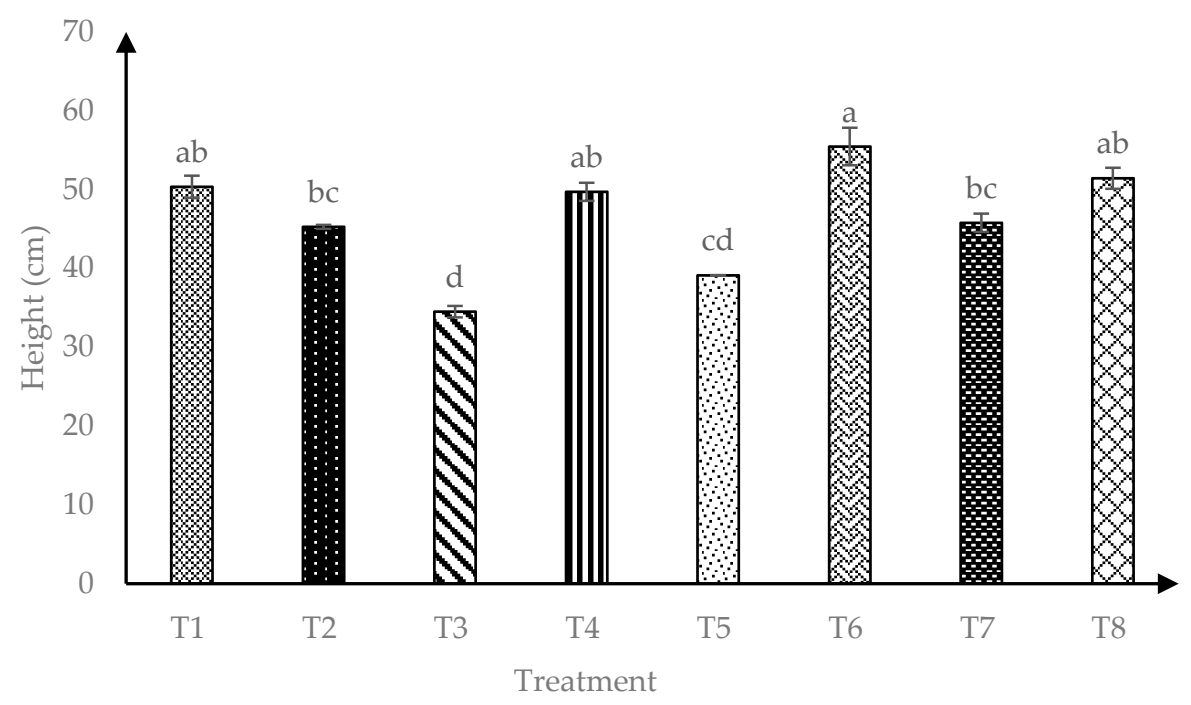

Figure 1. Effects of arbuscular mycorrhizal fungi (AMF) and rice husk biochar (RHB) on soursop height four months after transplanting. Means with similar small letter are not significantly different $(p>0.05)$ according to Tukey's HSD (Honest Significant Difference). T1 $=$ Control, $\mathrm{T} 2=+\mathrm{AMF}+$ 0 t/ha RHB, T3 = -AMF + 10 t/ha RHB, T4 = +AMF + 10 t/ha RHB, T5 = -AMF + 15 t/ha RHB, $\mathrm{T} 6=+\mathrm{AMF}+15 \mathrm{t} / \mathrm{ha} \mathrm{RHB}, \mathrm{T} 7=-\mathrm{AMF}+20 \mathrm{t} / \mathrm{ha} \mathrm{RHB}$ and $\mathrm{T} 8=+\mathrm{AMF}+20 \mathrm{t} / \mathrm{ha} \mathrm{RHB}$.

Interaction of AMF and RHB had significant effects on shoot biomass in which all treatments with RHB (T3, T4, T5, T6, T7 and T8) showed significantly $(p \leq 0.05)$ higher 
soursop shoot biomass than those not amended with RHB or inoculated with AMF (T1) (Table 1). This result implied that $10 \mathrm{t} /$ ha RHB gave similar results as higher RHB rates (15 t/ha and $20 \mathrm{t} / \mathrm{ha}$ ). In addition, $10 \mathrm{t} / \mathrm{ha}$ RHB and $15 \mathrm{t} / \mathrm{ha}$ RHB with AMF inoculation (T4 and T6) had better shoot biomass than treatments without RHB (T1 and T2).

Similar to shoot biomass, significant $(p \leq 0.05)$ interaction $\left(\mathrm{AMF}^{*} \mathrm{RHB}\right)$ on root biomass was also found at 120 days after transplanting (Table 1). All treatments with RHB with or without AMF (T4, T5, T6, T7 and T8) as well as soils with AMF alone (T2) gave similar results on soursop root biomass, but significantly higher than that in control (T1). Among these treatments, $+\mathrm{AMF}+10 \mathrm{t} /$ ha RHB (T4) produced the highest root biomass compared to $\mathrm{T} 1$ (control).

Table 1. Plant biomass of soursop seedling four months after transplanting.

\begin{tabular}{ccc}
\hline \multirow{2}{*}{ Treatment } & \multicolumn{2}{c}{ Plant Biomass (g) } \\
\cline { 2 - 3 } & Shoot & Root \\
\hline T1 & $2.35 \mathrm{c}$ & $0.92 \mathrm{c}$ \\
\hline T2 & $6.15 \mathrm{~b}$ & $3.50 \mathrm{ab}$ \\
\hline T3 & $8.73 \mathrm{ab}$ & $2.27 \mathrm{bc}$ \\
\hline T4 & $10.44 \mathrm{a}$ & $4.70 \mathrm{a}$ \\
\hline T5 & $8.53 \mathrm{ab}$ & $3.83 \mathrm{ab}$ \\
\hline T6 & $10.28 \mathrm{a}$ & $4.19 \mathrm{ab}$ \\
\hline T7 & $7.90 \mathrm{ab}$ & $3.76 \mathrm{ab}$ \\
\hline T8 & $7.89 \mathrm{ab}$ & $3.67 \mathrm{ab}$ \\
\hline Interaction (AMF*RHB) & $0.0237^{*}$ & $0.0166 *$ \\
\hline
\end{tabular}

Note: Means with similar small letter in column are not significantly different $(p>0.05)$ according to

Tukey's HSD (Honest Significant Difference). * Significant at $p \leq 0.05$ (ANOVA).

In terms of soursop specific leaf area (SLA), interaction of AMF and RHB had significant effects $(p \leq 0.05)$ as showed in Figure 2. A total of 120 days after transplanting, T3 and T7 produced similarly higher SLA than other treatments. Overall, soursop seedlings grown in soils amended with $10 \mathrm{t} /$ ha RHB were consistently maintained as the best treatment for highest SLA.

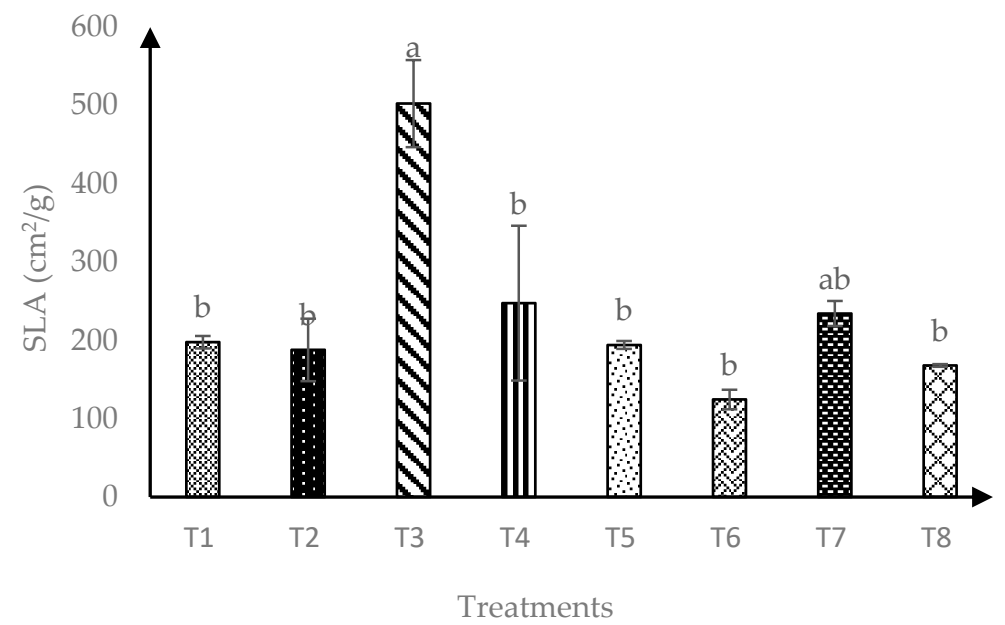

Figure 2. Specific leaf area of soursop seedlings four months after transplanting. Means with similar small letter were not significantly different $(p>0.05)$ according to Tukey's HSD (Honest Significant Difference). $\mathrm{T} 1=$ Control, $\mathrm{T} 2=+\mathrm{AMF}+0 \mathrm{t} / \mathrm{ha} \mathrm{RHB}, \mathrm{T} 3=-\mathrm{AMF}+10 \mathrm{t} / \mathrm{ha} \mathrm{RHB}, \mathrm{T} 4=+\mathrm{AMF}+$ 10 t/ha RHB, T5 = -AMF + 15 t/ha RHB, T6 = +AMF + 15 t/ha RHB, T7 = -AMF + 20 t $/$ ha RHB and $\mathrm{T} 8=+\mathrm{AMF}+20 \mathrm{t} / \mathrm{ha} \mathrm{RHB}$. 
Based on Figure 3, interaction of AMF and RHB showed significant effects ( $p \leq 0.05)$ on soursop root surface area (RSA). Four months after transplanting, all RHB treated soils and soils with AMF alone were observed to have similar RSA.

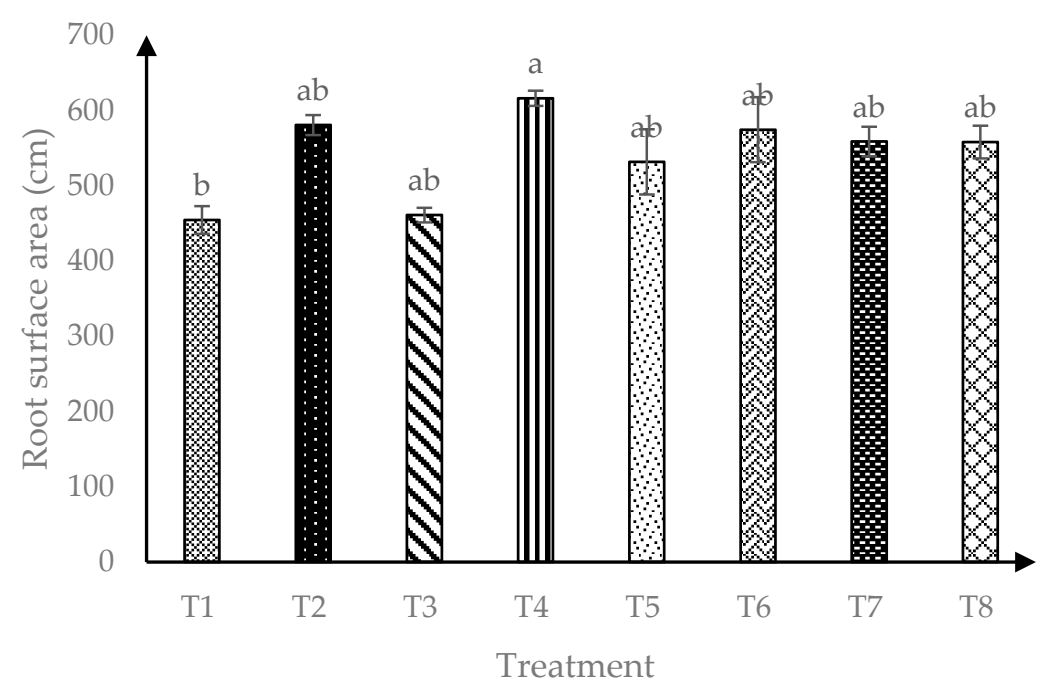

Figure 3. Root surface area of soursop seedlings four months after transplanting. Means with similar small letter are not significantly different $(p>0.05)$ according to Tukey's HSD (Honest Significant Difference). $\mathrm{T} 1=$ Control, $\mathrm{T} 2=+\mathrm{AMF}+0 \mathrm{t} / \mathrm{ha} \mathrm{RHB}, \mathrm{T} 3=-\mathrm{AMF}+10 \mathrm{t} / \mathrm{ha} \mathrm{RHB}, \mathrm{T} 4=+\mathrm{AMF}+$ $10 \mathrm{t} / \mathrm{ha} \mathrm{RHB}, \mathrm{T} 5=-\mathrm{AMF}+15 \mathrm{t} / \mathrm{ha} \mathrm{RHB}, \mathrm{T} 6=+\mathrm{AMF}+15 \mathrm{t} / \mathrm{ha} \mathrm{RHB}, \mathrm{T} 7=-\mathrm{AMF}+20 \mathrm{t} / \mathrm{ha} \mathrm{RHB}$ and $\mathrm{T} 8=+\mathrm{AMF}+20 \mathrm{t} / \mathrm{ha} \mathrm{RHB}$.

At 120 days after transplanting, soursop seedlings were significantly affected $(p \leq 0.05)$ by AMF*RHB interaction on soursop root length Figure 4. Control soil (-AMF $+0 \mathrm{t} / \mathrm{ha}$ RHB) had the lowest root length four months after transplanting. Both T6 and T1 produced similarly lowest root lengths at later harvest, implying negative effects of RHB at higher rate than $>10$ t/ha.

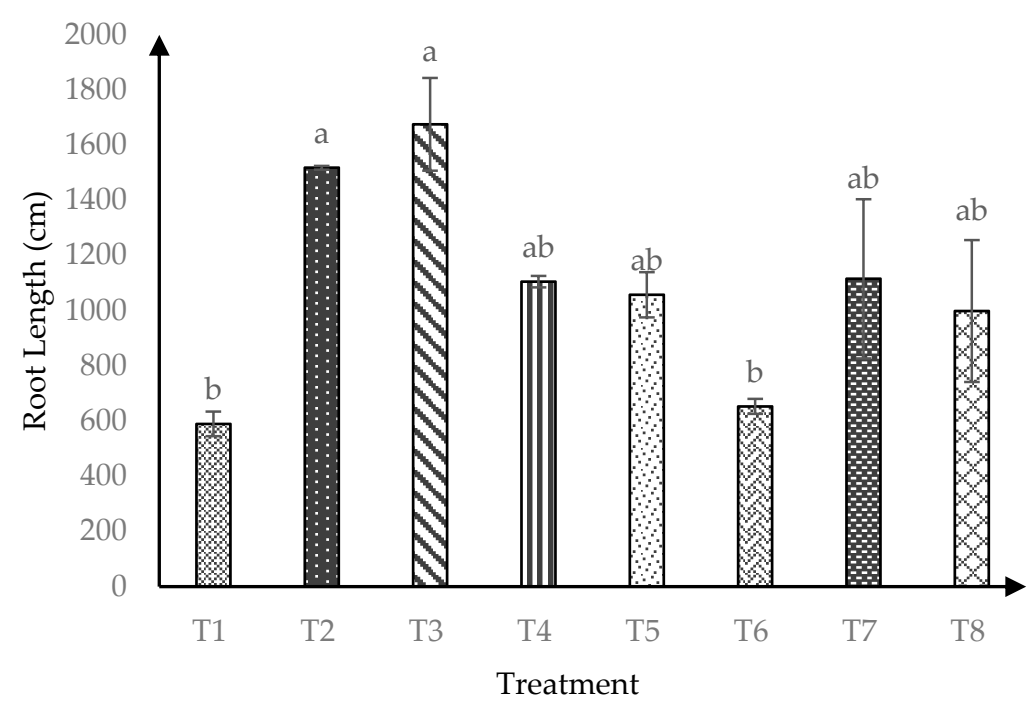

Figure 4. Root length of soursop seedlings four months after transplanting. Means with similar small letter are not significantly different $(p>0.05)$ according to Tukey's HSD (Honest Significant Difference). $\mathrm{T} 1=$ Control, $\mathrm{T} 2=+\mathrm{AMF}+0 \mathrm{t} / \mathrm{ha} \mathrm{RHB}, \mathrm{T} 3=-\mathrm{AMF}+10 \mathrm{t} / \mathrm{ha} \mathrm{RHB}, \mathrm{T} 4=+\mathrm{AMF}+$ $10 \mathrm{t} / \mathrm{ha} \mathrm{RHB}, \mathrm{T} 5=-\mathrm{AMF}+15 \mathrm{t} / \mathrm{ha} \mathrm{RHB}, \mathrm{T} 6=+\mathrm{AMF}+15 \mathrm{t} / \mathrm{ha} \mathrm{RHB}, \mathrm{T} 7=-\mathrm{AMF}+20 \mathrm{t} / \mathrm{ha} \mathrm{RHB}$ and $\mathrm{T} 8=+\mathrm{AMF}+20 \mathrm{t} / \mathrm{ha}$ RHB. 
Significant $(p \leq 0.05)$ interaction of AMF and RHB on root volume was found 120 days after transplanting as shown in Figure 5. The combination of RHB and AMF inoculation (T4, T6 and T8) produced higher root volume four months after transplanting compared to $0 \mathrm{t} / \mathrm{ha}$ RHB (T1 and T2). This trend implies that $10 \mathrm{t} / \mathrm{ha}$ RHB with AMF gave similar results with higher RHB rate ( $15 \mathrm{t} / \mathrm{ha}$ and $20 \mathrm{t} / \mathrm{ha}$ ).

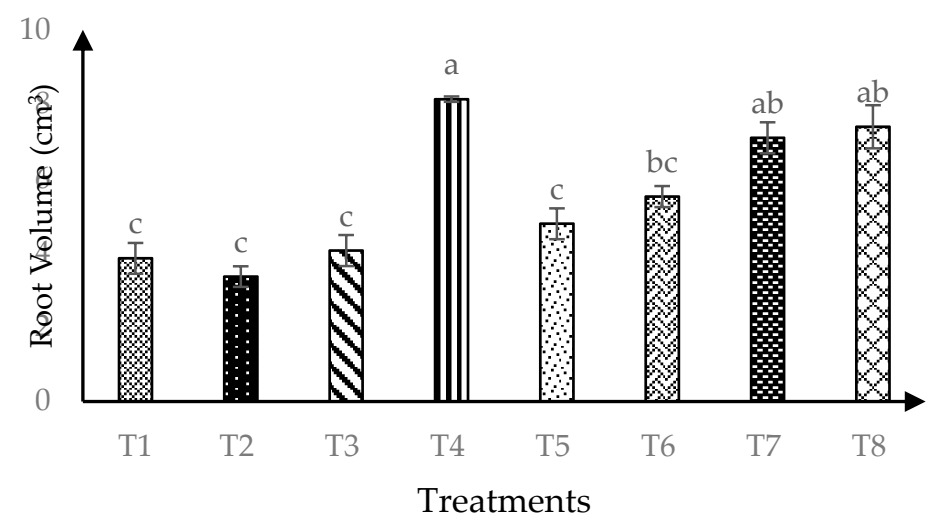

Figure 5. Root volume of soursop seedlings four months after transplanting. Means with similar small letter are not significantly different $(p>0.05)$ according to Tukey's HSD (Honest Significant Difference). $\mathrm{T} 1=$ Control, $\mathrm{T} 2=+\mathrm{AMF}+0 \mathrm{t} / \mathrm{ha} \mathrm{RHB}, \mathrm{T} 3=-\mathrm{AMF}+10 \mathrm{t} / \mathrm{ha} \mathrm{RHB}, \mathrm{T} 4=+\mathrm{AMF}+$ 10 t/ha RHB, T5 = -AMF + 15 t/ha RHB, T6 = +AMF + 15 t/ha RHB, T7 = -AMF + 20 t $/$ ha RHB and $\mathrm{T} 8=+\mathrm{AMF}+20 \mathrm{t} /$ ha RHB.

\subsection{Effects of AMF and RHB on Soil Microbial Properties}

AMF and RHB interaction significantly affected $(p \leq 0.05)$ bacterial and actinomycetes population but not the fungal population four months after transplanting (Table 2). For bacterial population, it was found that T1, T3, T4, T6 and T7 had similar soil bacteria population. However, T3 $(-\mathrm{AMF}+0 \mathrm{t} / \mathrm{ha} \mathrm{RHB})$ produced higher bacterial population than T2. For actinomycetes population, the results clearly show that T3 and T4 had the lowest population while T1 and T2 had higher actinomycetes population. This observation was opposite with results in bacterial population.

Meanwhile, as observed in fungal population soil treated with $0 \mathrm{t} / \mathrm{ha}$ RHB, $10 \mathrm{t} / \mathrm{ha}$ RHB and $20 \mathrm{t} / \mathrm{ha}$ RHB had higher fungal population $\left(2.18,2.31\right.$ and $2.17 \log _{10} \mathrm{cfu} / \mathrm{g}$ dry soil) compared to treatment $15 \mathrm{t} / \mathrm{ha}$ RHB.

Table 2. Soil microbial population four months after transplanting.

\begin{tabular}{cccc}
\hline \multirow{2}{*}{ Treatment } & \multicolumn{3}{c}{ Soil Microbial Population $\left(\log _{\mathbf{1 0}} \mathbf{c f u} / \mathbf{g}\right.$ Dry Soil) } \\
\cline { 2 - 4 } & Bacterial & Fungal & Actinomycetes \\
\hline T1 & $5.05 \mathrm{a}$ & $2.16 \mathrm{a}$ & $3.53 \mathrm{a}$ \\
\hline $\mathrm{T} 2$ & $4.79 \mathrm{~b}$ & $2.22 \mathrm{a}$ & $3.31 \mathrm{ab}$ \\
\hline $\mathrm{T} 3$ & $5.12 \mathrm{a}$ & $2.28 \mathrm{a}$ & $2.77 \mathrm{c}$ \\
\hline $\mathrm{T} 4$ & $5.01 \mathrm{a}$ & $2.34 \mathrm{a}$ & $3.12 \mathrm{abc}$ \\
\hline T5 & $4.90 \mathrm{ab}$ & $1.53 \mathrm{a}$ & $2.90 \mathrm{c}$ \\
\hline T6 & $5.05 \mathrm{a}$ & $1.94 \mathrm{a}$ & $2.93 \mathrm{bc}$ \\
\hline T7 & $5.05 \mathrm{a}$ & $2.20 \mathrm{a}$ & $3.12 \mathrm{bc}$ \\
\hline T8 & $4.97 \mathrm{ab}$ & $2.14 \mathrm{a}$ & $3.17 \mathrm{abc}$ \\
\hline Interaction $\left(\mathrm{AMF}{ }^{*} \mathrm{RHB}\right)$ & $0.0533^{*}$ & $0.2046^{\mathrm{ns}}$ & 0.0164 \\
\hline
\end{tabular}

Note: Means with similar small letter in column are not significantly different $(p>0.05)$ according to Tukey's HSD (Honest Significant Difference). ${ }^{*}$ Significant at $p \leq 0.05$ (ANOVA), ${ }^{\text {ns }}$ not significant at $p>0.05$ (ANOVA) 
From Table 3, there were no significant effects $(p>0.05)$ on root colonization four months after transplanting. Root colonization by AMF was not influenced by AMF but responded to $\mathrm{RHB}$ application. In general, soil treated with $\mathrm{RHB}$ at the application rate of $10 \mathrm{t} / \mathrm{ha}$ RHB to $20 \mathrm{t} / \mathrm{ha}$ RHB resulted in similarly higher AMF infection (78.0, 74.17, and $75.63 \log _{10} \mathrm{cfu} / \mathrm{g}$ dry soil) compared to $0 \mathrm{t} / \mathrm{ha}$ RHB.

Interaction of AMF and RHB (AMF*RHB) had significant effects $(p \leq 0.05) 120$ days after planting. In this study, mycorrhizal inoculated roots were highly infected by AMF at lower RHB rate $<10 \mathrm{t} /$ ha (T2 and T4) compared to higher RHB application rate, especially at 15 t/ha RHB (T6).

Table 3. Root infection and AMF spore four months after transplanting.

\begin{tabular}{ccc}
\hline Treatment & Root infection (\%) & No of Spore/10 g of Soil \\
\hline T1 (Control) & $45.00 \mathrm{a}$ & $3.00 \mathrm{~d}$ \\
\hline T2 & $43.89 \mathrm{a}$ & $18.67 \mathrm{a}$ \\
\hline T3 & $83.90 \mathrm{a}$ & $3.00 \mathrm{~d}$ \\
\hline T4 & $73.75 \mathrm{a}$ & $15.50 \mathrm{ab}$ \\
\hline T5 & $77.50 \mathrm{a}$ & $1.67 \mathrm{~d}$ \\
\hline T6 & $70.83 \mathrm{a}$ & $8.67 \mathrm{c}$ \\
\hline T7 & $70.84 \mathrm{a}$ & $1.67 \mathrm{~d}$ \\
\hline T8 & $80.42 \mathrm{a}$ & $11.00 \mathrm{bc}$ \\
\hline Interaction $\left(A M F^{*}\right.$ RHB $)$ & $0.0636 \mathrm{~ns}$ & $<0.0001$ \\
\hline
\end{tabular}

Note: Means with similar small letter in column are not significantly different $(p>0.05)$ according to Tukey's HSD (Honest Significant Difference). ${ }^{\text {ns }}$ not significant at $p>0.05$ (ANOVA).

\section{Discussion}

\subsection{Effects of AMF and RHB on Soursop Plant Growth}

Application of AMF, RHB and their interaction had significant effects on growth of soursop growth. Biochar application to soil positively interacted with AMF and influenced AMF development, hence soil properties and plant growth [25]. A total of 120 days after transplanting, plant growth in terms of plant height showed the highest results in T6 (+AMF + $15 \mathrm{t} /$ ha RHB). Our observation was similar with a previous study which found that addition of RHB increased plant height of rice [26]. Besides, other studies have also shown that crop productivity increased $11 \%$ on average when RHB dose applied was $<30 \mathrm{t} /$ ha [2].

In this study, it is important to note that biochar effect in plant productivity is dependent on the rate of RHB application. Results showed that soursop plants were more dependent on RHB than without RHB. This can be associated to RHB characteristics as well.

The majority of data measured followed the trend in which treatments of AMF with RHB either at $10 \mathrm{t} /$ ha or $15 \mathrm{t} /$ ha stimulated plant growth and uptake (data not shown). In some cases, $20 \mathrm{t} /$ ha RHB was detrimental to plants 120 days after transplanting as exhibited in lower SLA compared to $10 \mathrm{t} / \mathrm{ha}$ RHB. Our work is in line with the previous work in Thailand, in which $10 \mathrm{t}$ /ha RHB application gave positive effects on soy bean growth and yield when planted in low fertility sandy soil [27]. A total of 120 days after transplanting, $10 \mathrm{t} /$ ha RHB with or without AMF (when compared to control) was found to be significantly highest in shoot and root biomass, root surface area, root length, specific leaf area (SLA) and AMF spores. Our work was also in accordance to previous findings on biochar's positive effects on plant growth [28].

In addition, root development was better in all treatments treated with RHB. Treatment T4 (+AMF + 10 t/ha RHB) showed higher root surface area; meanwhile $10 \mathrm{t} / \mathrm{ha}$ RHB alone produced higher root length. Ref. [29] recommended that biochar addition can help establishment of roots in soil. Ref. [3] proposed that biochar itself contains small amount of nutrient that are available to both soil biota including AMF and plant root. 
Soursop plant growth and nutrient uptake relied on AMF inoculation alone when there was no RHB being added to soils. The improvement of plant growth (for example shoot and root biomass) due to AMF inoculation confirmed the fact that AMF is capable of helping the host plant to absorb more water and nutrients [11]. Current findings also noted promotion in root growth in terms of root biomass, length, root surface area and root volume due to AMF inoculation. Similarly, Ref. [30] has documented that the application of AMF can help to enhance the development of root growth. Promotion in root growth by AMF was also found to be correlated to key plant measurements, such as an increase in plant nutrient uptake and secondary metabolites production. Underlying mechanisms and explanation involving AMF inoculation (either in 0 t/ha RHB, 10 t/ha RHB, 15 t/ha or 20 t/ha RHB), improvement in root growth and other plant measurements were associated to direct and indirect mechanisms. Root growth, especially root surface area, was stimulated by AMF and showed AMF capability to stimulate plant growth [31]. In all, these mechanisms took place when AMF hyphae acted as extra roots, and elongated roots allow larger soil volume to be explored for more nutrient and water uptake availability and uptake [32].

\subsection{Effects of AMF and RHB on Soursop Soil Microbial Properties}

Inoculation of AMF significantly affected the soil microbial population and the number of AMF spore in soil. Based on the data, AMF sporulated better in treatment with AMF only, with a high number of spores compared to other treatments. While root infection was higher in soursop with AMF inoculation, the spore number were promoted by the application of AMF. This would be a positive AMF development that indicates better symbiotic association with the plant itself and could give benefits to the host plants, in this study to soursop. Organic fertilizer practices developed mycorrhizal colonization in soursop but inhibited A. longula sporulation [33]. Thus, we can conclude that the AMF species used in this study may respond differently to organic matter (RHB) in soursop roots in terms of sporulation and infection in roots.

Preliminary study reported that Annona muricata showed a strong dependence on AMF formation for optimal growth and development [34]. The results showed that the effects of AMF interaction with varying RHB rate was not clear on soil microbial activity and population in soil. Normally, AMF hyphal glomalin and plant root exudates were able to stimulate microbial population in soil [35]. The application of AMF can help in increasing population density of bacteria in the rhizosphere [36]. Biochar might be beneficial to microbial population by serving as a source of reduced carbon compound and by increasing micronutrients availability. Only general effects of AMF comparable to non-AMF was found in bacterial population. In line with this, biochar was able to interact with soil physical and chemical characteristics as well as biological in soil [37]. Although no clear response was noted for AMF root colonization in roots, AMF spores increased in combination of RHB treated soils with AMF inoculation. Thus, in summary, interaction of AMF and RHB especially at $10 \mathrm{t} /$ ha RHB can be applied to grow soursop plant seedlings to obtain better plant growth.

\section{Conclusions}

Interaction of AMF with RHB showed that AMF with $10 \mathrm{t} /$ ha RHB gave similar effects to the higher RHB. When there was no significant interaction, soursop plant growth relied mostly on addition of RHB compared to no RHB application. Based on this experiment, the best treatment was $10 \mathrm{t} / \mathrm{ha}$ RHB with and without AMF. AMF species inoculated in this study (Glomus mosseae) confirmed previous studies that AMF were able to form symbiotic association with soursop plant as reflected in higher infection in roots [34]. In our case, Glomus mosseae inoculated treatments at lower RHB rate $(<10 \mathrm{t} / \mathrm{ha}$ RHB) were effective for AMF symbiosis and functioned in benefiting the host plant (soursop) root growth, hence improving the uptake of nutrients compared to higher RHB application rate especially $>15 \mathrm{t} / \mathrm{ha}$ (T6). This is possibly due to the AMF species itself which is familiar with tropical soil conditions. Therefore, more studies are needed to allow biochar usage in the 
nursery stage and establishment of mycorrhizal in soursop seedlings. The role of AMF in soursop cultivation in Malaysia soils also should be further explored in term of AMF species compatibility, suitability and host performance.

Author Contributions: Conceptualization, N.M.J.; methodology, N.M.J.; software, N.S.N.H.; validation, N.M.J. and N.S.N.H.; formal analysis, N.S.N.H.; investigation, N.S.N.H.; resources, N.M.J.; data curation, N.S.N.H.; writing—original draft preparation, N.S.N.H.; writing—review and editing, N.M.J.; visualization, N.M.J.; supervision, N.M.J. and S.Z.S.; project administration, N.M.J. and N.S.N.H.; funding acquisition, N.M.J. All authors have read and agreed to the published version of the manuscript.

Funding: This study was funded by UPM (GP-IPM/2015/9462400: Arbuscular mycorrhizal fungi inoculation for improved soursop (Annona muricata) growth and bioactive compounds).

Institutional Review Board Statement: Not applicable.

Informed Consent Statement: Not applicable.

Data Availability Statement: The data reported in this study is contained within the article.

Acknowledgments: The authors thanked Radziah Othman for generous assistance provided to this study, as well as Universiti Putra Malaysia for providing the facilities and field area to conduct this experiment.

Conflicts of Interest: The authors declare no conflict of interest.

\section{References}

1. Kaewpradit, W.; Toomsan, B.; Cadisch, G.; Vityakon, P.; Limpinuntana, V.; Sejan, P.; Jogloy, S.; Patanothai, A. Mixing groundnut residues and rice straw to improve rice yield and $\mathrm{N}$ use efficiency. Field Crops Res. 2009, 110, 130-138. [CrossRef]

2. Manickam, T.; Cornelissen, G.; Bachmann, R.T.; Illani, Z.I.; Mulder, J.; Sarah, E.H. Biochar Application in Malaysian Sandy and Acid Sulfate Soils: Soil Amelioration Effects and Improved Crop Production over Two Cropping Seasons. Sustainability 2015, 7, 16756-16770. [CrossRef]

3. Yamato, M.; Okimori, Y.; Wibowo, I.F.; Anshiori, S.; Ogawa, M. Effects of the application of charred bark of Acacia mangium on the yield of maize, cowpea and peanut, and soil chemical properties in South Sumatra, Indonesia. Soil Sci. Plant Nutr. J. 2006, 52, 489-495. [CrossRef]

4. Chan, K.; Van Zwieten, L.; Meszaros, L.; Downie, A.; Joseph, S. Agronomic values of greenwater biochar as a soil amendment. Soil Res. 2008, 45, 629-634. [CrossRef]

5. Deenik, J.L.; McClellan, T.; Uehara, G.; Antal, N.J.; Campbell, S. Charcoal volatile matter content influences plant growth and soil nitrogen transformations. Soil Sci. Soc. Am. J. 2010, 74, 1259-1270. [CrossRef]

6. Ezawa, T.; Smith, S.E.; Smith, F.E. P metabolism and transport in MA fungi. Plant Soil 2002, 244, 221-230. [CrossRef]

7. Glaser, B. Prehistorically modified soils of central Amazonia: A model for sustainable agriculture in the twenty first century. Philosophical transactions of the royal society. Biol. Sci. 2007, 362, 187-196. [CrossRef] [PubMed]

8. Jaafar, N.M.; Clode, P.L.; Abbott, L.K. Soil microbial responses to biochars varying in particle size, surface and pore properties. Pedosphere 2015, 25, 770-780. [CrossRef]

9. Blackwell, P.; Krull, E.; Butler, G.; Herbert, A.; Solaiman, Z. Effect of banded biochar on dryland wheat production and fertiliser use in south western Australia: An agronomic and economic perspective. Aust. J. Soil Res. 2010, 48, 531-545. [CrossRef]

10. Lai, L.; Ismail, M.R.; Muharam, F.M.; Yusof, M.M.; Ismail, R.; Jaafar, N.M. Effects of rice straw biochar and nitrogen fertilizer on rice growth and yield. Asian J. Crop Sci. 2017, 9, 159-166. [CrossRef]

11. Milla, O.V.; Rivera, E.B.; Huang, W.J.; Chien, C.; Wang, Y.M. Agronomic properties and characterization of rice husk and wood biochars and their effect on the growth of water spinach in a field test. J. Soil Sci. Plant Nutr. 2013, 13, $251-266$.

12. Antal, M.J.; Groli, M. The art, science and technology of charcoal production. Ind. Eng. Chem. Res. 2003, 42, 1619-1640. [CrossRef]

13. Chan, K.Y.; Xu, Z. Biochar: Nutrient properties and their enhancement. In Biochar for Environmental Management: Science and Technology; Lehmann, J., Joseph, S., Eds.; Earthscan: London, UK, 2009; pp. 67-84.

14. Rovica, R. Oil Palm Empty Fruit Bunch Biochar and Compost as Amendment for Improvement of Polybag-Growing Media and Oil Palm Seedlings. Master's Thesis, Universiti Putra Malaysia, Seri Kembangan, Malaysia, 2017.

15. Zahidah, A.R.; Rosenani, A.B.; Siti Hajar, A.; Radziah, O. Effect of rice husk biochar and chicken manure as a soil amendment on yield, heavy metals and nutrient uptake of Phyllanthus niruri. Int. J. Agric. Environ. Res. 2017, 3, 3667-3681.

16. Steiner, C.; Teixeira, W.G.; Lehmann, J.; Nehls, T.; de Macedo, J.L.V.; Blum, W.E.H.; Zech, W. Long term effects of manure, charcoal and mineral fertilization on crop production and fertility on a highly weathered central Amazonian upland soil. Plant Soil 2007, 291, 275-290. [CrossRef]

17. Solaiman, Z.; Murphy, D.V.; Abbott, L.K. Biochars influence seed germination and early growth of seedlings. Plant Soil 2011, 353, 237-287. [CrossRef] 
18. Liu, X.Y.; Zhang, A.; Ji, C.Y.; Joseph, S.; Bian, R.J.; Li, L.Q.; Pan, G.X.; Paz-Ferreiro, J. Biochar's effect on crop productivity and the dependence on experimental conditions-a meta-analysis of literature data. Plant Soil 2013, 373, 583-594. [CrossRef]

19. Ndor, E.; Jayeoba, O.J.; Asadu, C.L.A. Effect of biochar soil amendment on soil properties and yield of sesame varieties in Lafia, Nigeria. Am. J. Exp. Agric. 2015, 9, 1-8. [CrossRef]

20. Van Zwieten, L.; Kimber, S.; Downie, A.; Morris, S.; Petty, S.; Rust, J.; Chan, K.Y. A glasshouse study on the interaction of low mineral ash biochar with $\mathrm{N}$ in a sandy soil. Aust. J. Soil Res. 2010, 48, 569-576. [CrossRef]

21. Mekuria, W.; Noble, A. The role of biochar in ameliorating disturbed soils and sequestering soil carbon in tropical agriculture production systems. Appl. Environ. Soil Sci. 2013, 2013, 354965. [CrossRef]

22. Jaafar, N.M.; Clode, P.L.; Abbott, L.K. Microscopy observations of habitable space in biochar for colonization by fungal hyphae from soil. J. Integr. Agric. 2014, 13, 483-490. [CrossRef]

23. Gerdemann, J.W.; Nicolsons, T.H. Spores of mycorrhizal endogone extracted from soil by wet sieving and decanting. Trans. Br. Mycol. Soc. 1963, 46, 235-244. [CrossRef]

24. Parkinson, D.D.; Gray, R.G.; Williams, S.T. Methods for Studying the Ecology of Soils Microorganisms; Blackwell Publishing: Oxford, UK, 1971; p. 116.

25. Sarah Chandran, C.; Thomas, S.; Unni, M.R. Organic Farming: New Advances towards Sustainable Agriculture System; Spinger: Cham, Switzerland, 2019; p. 127.

26. Masulili, A.; Utomo, W.H.; Syechfani, M. Rice husk biochar for rice-based cropping system in acid soil. The characterisation of rice husk biochar and its influence on the properties of acid sulfate soils and rice growth in west Kalimantan, Indonesia. J. Agric. Sci. 2010, 2, 39-47.

27. Oka, H.; Rungrattanaksin, W. Improvement of sandy soil in the northeast by using carbonized rice husks. ICA Tech. Rep. 1993, 13, 40-42.

28. Doyle, R.B.; Close, D.C. Biochar media addition impacts apple rootstock growth and nutrition. Hort Sci. 2014, $49,1188-1193$.

29. Brennan, A.; Jimenez, E.M.; Puschenreiter, M.; Alberquerque, J.A.; Switzer, C. Effects of biochar amendment on root traits and contaminant availability of maize plants in a copper and arsenic impacted soil. Plant Soil 2014, 379, 351-360. [CrossRef]

30. Hodge, A. Microbial ecology of the arbuscular mycorrhiza. Mini Review in FEMS. Microbiol. Ecol. 2000, 32, 91-96. [CrossRef]

31. Syafieqa, M.Z. Effect of Different Mycorrhizal Inoculums on Growth and Yield of Okra (Ablemoschus esculentus L.); Universiti Putra Malaysia: Seri Kembangan, Malaysia, 2015.

32. Syahidah, N.R. Effects of Arbuscular Mycorrhiza Fungi and Fertilizer on the Growth of Soursop (Annona muricata L.); Universiti Putra Malaysia: Seri Kembangan, Malaysia, 2016.

33. Silva, D.K.A.; Silva, F.S.B.; Yano-Melo, A.M.; Maia, L.C. Uso de vermicomposto favorece o crescimento de mudas de gravioleira (Annona muricata L. 'Muricata') associada a fungos micorrízicos arbusculares. Acta Bot Bras. 2008, 22, 863-869. [CrossRef]

34. Azcon-Aguilar, C.; Azcon, R.; Encina, C.L.; Barea, J.M. Effect of arbuscular mycorrhiza on the growth and development of micropropagated Annona cherimola plants. Agric. Food Sci. 1994, 3, 281-288. [CrossRef]

35. Johansson, R.C.; Gowda, P.H.; Mulla, D.J.; Dalzell, B.J. Metamodelling phosphorus best management practices for policy use: A frontier approach. Agric. Econ. 2004, 30, 63-74. [CrossRef]

36. Medina, A.; Probanza, A.; Manero, F.G.; Azcon, R. Interaction of arbuscular mycorrhizal fungi and Bacillus strains and their effects on plant growth, microbial rhizosphere activity (thymidine and leucine incorporation) and fungal biomass (ergosterol and chitin). Appl. Soil Ecol. 2003, 22, 15-28. [CrossRef]

37. Lehmann, J.; Rillig, M.C.; Thies, J.; Masiello, C.A.; Hockaday, W.C.; Crowley, D. Biochar effects on soil biota-A review. Soil Biol. Biochem. 2011, 43, 1812-1836. [CrossRef] 